\title{
THE LACTIC ACID OF THE BLOOD IN HEPATIC DISEASE ${ }^{1}$
}

\author{
By ALBERT M. SNELL AND GRACE M. ROTH ${ }^{2}$ \\ (From the Division of Medicine, The Mayo Clinic, Rochester, Minn.)
}

(Received for publication May 2, 1932)

\section{LITERATURE}

The relation of the liver to the metabolism of carbohydrates has attracted the attention of investigators since Minkowski (1886) demonstrated a decrease in blood sugar and an increase of excretion of lactic acid in the urine of hepatectomized geese. The function of the liver in the maintenance of the normal value for blood sugar is now fully established (Mann and Magath) and attention naturally turns to the intermediate products of metabolism of carbohydrate such as lactic acid. Von Noorden and Embden (1906) first advanced the idea of a carbohydrate cycle between liver and muscle, and suggested that the lactic acid formed by muscular contraction was returned to the liver to be stored as glycogen. This view has been fully confirmed by recent investigators, notably by Himwich and his collaborators and by Cori and Cori. It is now recognized that in the normal resting organism some lactic acid passes from the muscles to the blood, and small amounts ( 7 to $18 \mathrm{mgm}$. each hour) appear in the urine. Much larger amounts of this substance appear in both blood and urine after exercise; the quantity is affected considerably by the degree of "oxygen debt." The liver undoubtedly removes a considerable part of this excess lactic acid from the circulation and stores it as glycogen. It has been shown (Schneider and Widmann) that the liver is capable of retaining considerable amounts of optically inactive lactic acid injected into the portal vein; the concentration of lactic acid of the hepatic venous blood is not increased, nor is its optical activity increased.

From the foregoing, it is evident that the functional efficiency of the hepatic parenchyma must have a considerable effect on the value for lactic acid in the blood, and on the rate with which the accumulations of this substance are removed following exercise. As the recent experiments of Eggleton and Evans disclosed, the liver is not the only agent in removing lactic acid from the blood. The heart and brain take up this substance readily, and resting muscles absorb some of the lactic acid liberated by working muscles. Considerable amounts may also be lost in the perspiration.

Muscular exercise is, of course, the factor most likely to produce an increase in lactic acid of the blood in the individual case. Other factors also elevate the value for lactic acid of the blood; among these may be mentioned cardiac decompensation with circulatory failure (Meakins and Long), anemia, anoxemia, prolonged vomiting, irradiation, ether narcosis (Ronzoni and coworkers), and administration of various sugars (Campbell and Maltby, Wierzuchowski

1 Read before the American Society for Clinical Investigation, Atlantic City, New Jersey, May 2, 1932.

${ }^{2}$ Fellow in Hematology, The Mayo Foundation. 
and Laniewski). The presence of carcinoma is also said to increase the concentration of lactic acid in the blood (Büttner, Valentin, Schumacher, Gelstein and Frankstein). In general, the value for lactic acid of the blood is highly variable, and all of the factors mentioned must be taken into consideration when one attempts to evaluate the individual test. The general significance of lactic acid in the organism, and the factors which influence its metabolism in health and disease, recently have been considered in detail by Himwich, by Jervell and by Cori and need not be considered in further detail here.

A number of papers $(1,2,3,4,6,10,14,20,21,23,28,29,33,34,35,36)$ on the value for lactic acid in the blood in cases of hepatic disease and in experimental hepatic injury have appeared in the last few years. Although there are variations in the methods used and in the results obtained, most investigators agree that in the more severe degrees of hepatic injury, there is an increase in the lactic acid of the blood. This increase may be slight and inconstant in association with minor degrees of hepatic injury, and is of ten small even in severe cases. It has also been shown that there is delay in the disappearance of lactic acid from the circulation following injection of lactates into patients with hepatic disease and in animals with experimental lesions of the liver. Again, widely varying amounts of lactate have been given by various authors, and the results are not altogether in agreement. The recent studies of Bollman and Mann, of the metabolism of lactic acid following hepatectomy performed on dogs, and similar studies by Drury and McMaster on hepatectomized rabbits, constitute the principal reason for reopening the subject at the present time. Briefly, these workers have found that removal of the liver is followed by increase in the lactic acid content of the blood and urine. The initial increase, which usually reaches a value about double the normal amount, is probably due chiefly to ether anesthesia, since the value for lactic acid of the blood falls during the period of recovery. A somewhat greater terminal increase is also noted in the majority of animals just before death. Neither development of hypoglycemia nor injection of glucose appears to affect the value for lactic acid in the blood after hepatectomy (Bollman and Mann). Bollman and Mann showed that following intravenous injection of lactic acid or sodium lactate into these liverless animals, the value for lactic acid of the blood increases sharply. Only a small portion of this injected lactic acid (approximately 20 per cent) is excreted in the urine, and the amount present in the blood returns to its previous level in a short period. These changes in lactic acid of the blood noted after hepatectomy give a standard of comparison for the study of this subject in clinical cases of hepatic disease, and furnish some idea of what might be expected in clinical conditions of hepatic insufficiency.

\section{MATERIAL AND METHODS}

The present study consists of 250 determinations of lactic acid of the blood. The subjects studied included normal persons under varying conditions of exercise and activity and patients with hepatic disorders of various types, eighty in all. In certain cases it was possible to make repeated determinations of lactic acid at various stages of hepatic disease, and thus to study any relationship that may exist between the clinical condition of the patient and the lactic acid content of the blood. Determinations of lactic acid were also made before and after surgical operation 
for relief of obstructive jaundice due to stone in the common bile duct, to carcinoma, and to stricture. The values for lactic acid of the blood were also determined in a small group of cases following intravenous injection of solutions of sodium lactate.

Lactic acid was determined by the method of Friedemann and Kendall. With persons under basal conditions, the normal value for lactic acid, as determined by this method, lies between 8 and $15 \mathrm{mgm}$. in each $100 \mathrm{cc}$. of blood. Even slight muscular exertion increased this value considerably, but in general it was found that twenty to thirty minutes in the prone position following moderate degrees of muscular activity, was sufficient to restore to normal the proportion of lactic acid in the blood. It is obvious, of course, that after more prolonged and vigorous activity, a longer period is required before the basal level is reached. The use of a tourniquet was avoided whenever possible, but in our experience the very brief period of venous stasis required to obtain a sample of blood had little, if any, effect on the result obtained. This has also been the experience of Hewlett, Barnett and Lewis. Prolonged venous stasis may produce a considerable elevation of the value for lactic acid in the blood (Mendel and his coworkers), but it is rarely if ever necessary to cause prolonged venous stasis in obtaining specimens of blood.

In general it was found that hepatic disease produced slight to moderate elevations in the value for lactic acid in the blood. The greatest rises were noted among patients who gave clinical evidence of severe intrahepatic types of jaundice, and among patients with carcinomatous obstruction of the biliary passages. The data on a representative group of these cases are presented graphically in Figure 1. The additional cases gave results in accord with these figures.

The findings are in accord with those of other observers, and no doubt the changes noted represent interference with normal recovery of lactic acid by the liver. The increases noted are fully as great as those observed in work with many animals after hepatectomy; this will be considered later. It is of interest to note that the values for lactic acid in the blood rarely exceed the renal threshold of 30 to $40 \mathrm{mgm}$. for each $100 \mathrm{cc}$. of blood as established by Hewlett, Barnett and Lewis. Apparently renal elimination constitutes a check on the accumulation of lactic acid in the blood, and further studies of urinary excretion of this substance are being made in order to corroborate this hypothesis.

Loeb and his coworkers stated that there is no demonstrable relationship between either the clinical condition of the patient or the degree of bilirubinemia and the observed values for lactic acid of the blood. An attempt at correlation between the values for serum bilirubin and those for lactic acid is illustrated graphically in Figure 2. It is obvious that no close correlation exists; the actual correlation coefficient is calculated as 0.1. However, these data appear to show that increases in serum 
bilirubin are consistently associated with values for lactic acid which are above normal. It is evident that no very close correlation can be expected among patients with obstructive jaundice, since the value for bilirubin among these patients may fluctuate considerably from day to

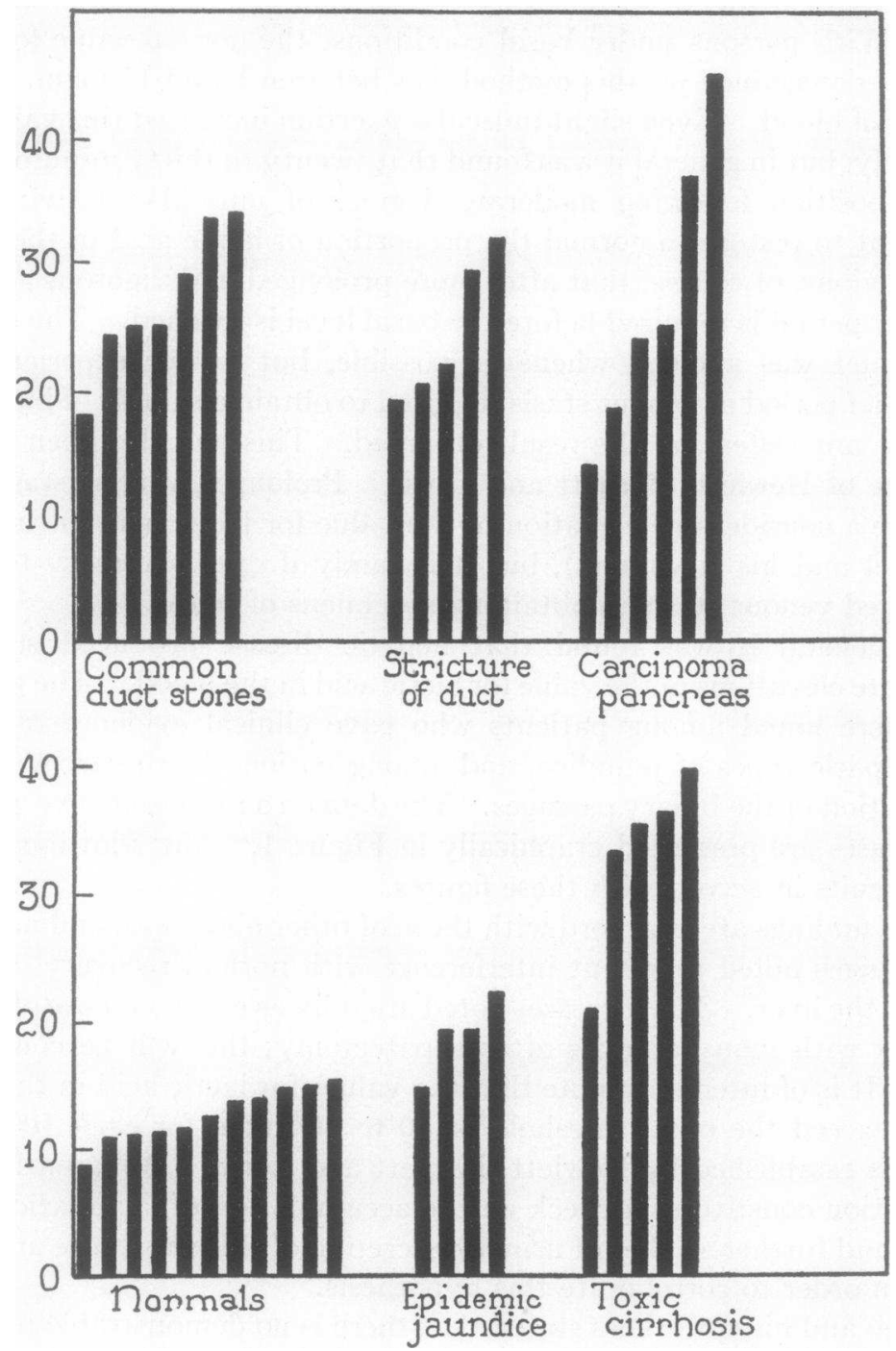

Fig. 1. The Content of Lactic Acid of Blood in Normal Persons and in Patients with Various Types of Hepatic Disease

day, and may be affected by many factors not necessarily connected with the functional efficiency of the hepatic cell. In jaundice due primarily to hepatic parenchymal injury, a closer correlation may exist. In one case 


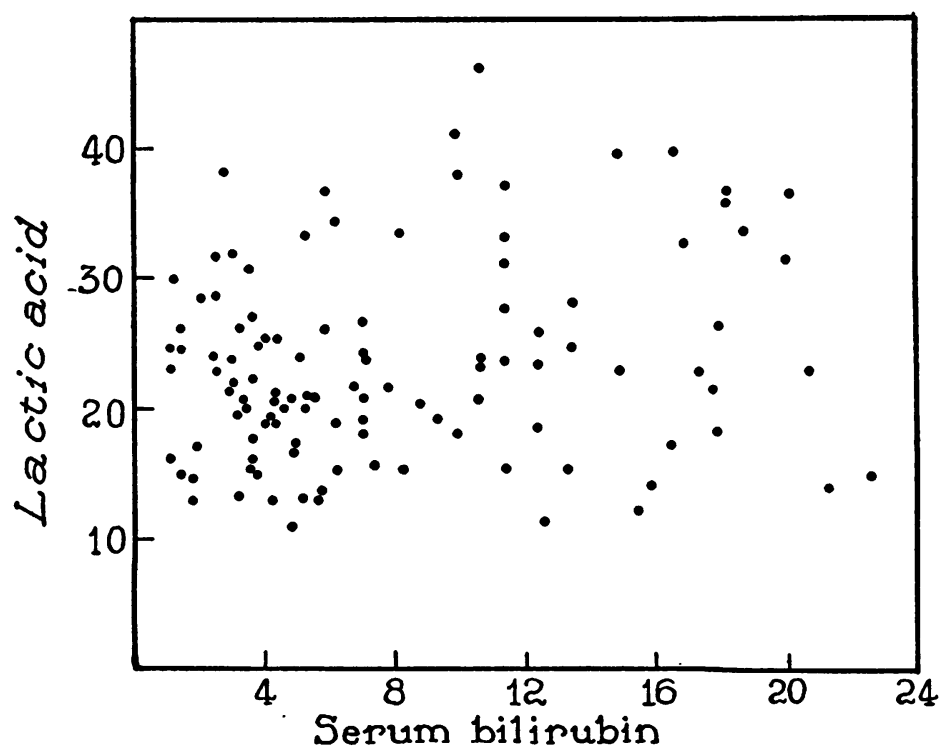

Fig. 2. The Relation of Serum Bilirubin and Lactic Acid in the Blood in Jaundiced Patients

of hepatitis due to arsphenamine, the values for lactic acid and bilirubin during the stage of recovery paralleled each other closely (Fig. 3). In one case of infectious jaundice, similar correlation was noted.

It is recognized that in mechanical obstruction to the bile passages

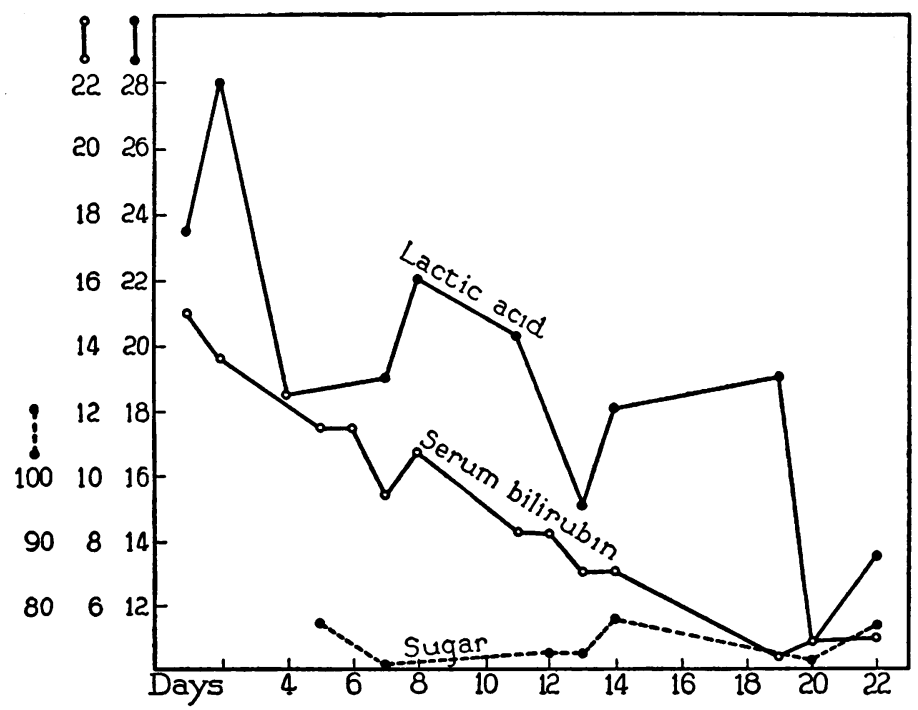

Fig. 3. Values for the Serum Bilirubin and Lactic Acid in the Blood in a Patient with Arsphenamine Hepatitis 
a considerable degree of hepatic parenchymal injury occurs. In favorable cases this is probably repaired rather promptly following relief of biliary obstruction. It is also known that the glycogen content of the liver is greatly decreased in the presence of mechanical obstruction to the biliary passages, and that it returns to normal when the obstruction is relieved. Under basal conditions the values for lactic acid of the blood, following surgical relief of biliary obstruction, vary in a way that may be correlated, in general, with these changes (Table 1). In favorable cases there is a

TABLE 1

Values for lactic acid and other constituents of the blood before and after relief of biliary obstruction

\begin{tabular}{|c|c|c|c|c|c|}
\hline \multirow{3}{*}{ Remarks } & \multirow{3}{*}{ Date } & \multicolumn{4}{|c|}{ Constituents } \\
\hline & & \multicolumn{3}{|c|}{ Blood } & \multirow{2}{*}{ Serum } \\
\hline & & Lactic acid & Sugar & Urea & \\
\hline $\begin{array}{l}\text { Choledocholithiasis, diabetes } \\
\text { mellitus }\end{array}$ & \begin{tabular}{c|}
1932 \\
February 26
\end{tabular} & $\begin{array}{c}\text { mgm. per } \\
100 \text { cc. } \\
24.9\end{array}$ & $\begin{array}{c}\text { mgm. per } \\
100 \text { cc. } \\
162\end{array}$ & $\begin{array}{c}\underset{100 \text { cc. }}{\text { mgm. per }} \\
20\end{array}$ & $\begin{array}{c}\underset{100}{\text { mgm. per }} \\
4.1 \\
4.1\end{array}$ \\
\hline Following biliary colic & February 27 & & & & 9.4 \\
\hline Second biliary colic & March 1 & 41.1 & 207 & & 10.0 \\
\hline Choledocholithotomy & $\begin{array}{lr}\text { March } & 3 \\
\text { March } & 7 \\
\text { March } & 10 \\
\text { March } & 14 \\
\text { March } & 17 \\
\text { March } & 22 \\
\text { March } & 24\end{array}$ & $\begin{array}{l}21.2 \\
23.9 \\
21.9 \\
20.1 \\
10.8 \\
12.6\end{array}$ & $\begin{array}{r}117 \\
110 \\
101 \\
\\
87\end{array}$ & 26 & $\begin{array}{l}5.4 \\
5.2 \\
5.8 \\
4.7 \\
4.7 \\
4.3\end{array}$ \\
\hline Patient up and about & $\begin{array}{lr}\text { March } & 28 \\
\text { April } & 1\end{array}$ & $\begin{array}{l}22.1 \\
22.1\end{array}$ & 97 & & $\begin{array}{l}3.2 \\
2.5\end{array}$ \\
\hline
\end{tabular}

temporary rise of lactic acid in the blood following operation, due probably to the effect of anesthesia. This is followed by a period of decline until a resting normal level is established. As soon as the patient is permitted to be up and about, however, a rather constant rise in the value for lactic acid is noted. This rise was observed in several cases, and can be attributed to factors involving muscular and circulatory efficiency rather than to the liver. In cases in which failure to recover follows relief of biliary obstruction, the value for lactic acid increases rather than declines, and may reach high levels as the clinical condition of "hepatic insufficiency" develops. Data in a group of such cases are presented in Table 2. It will be noted that very high levels for lactic acid and the 
ALBERT M. SNELL AND GRACE M. ROTH

\begin{tabular}{|c|c|c|c|c|c|c|c|c|}
\hline & 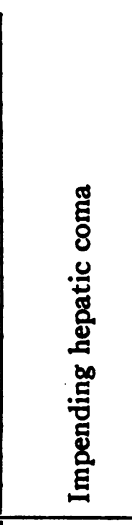 & 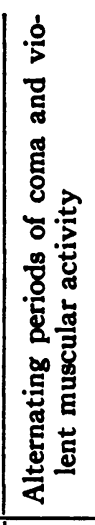 & 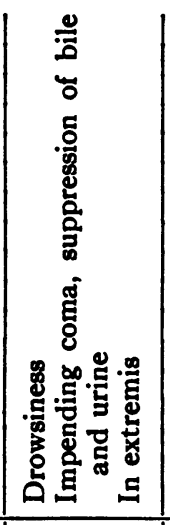 & 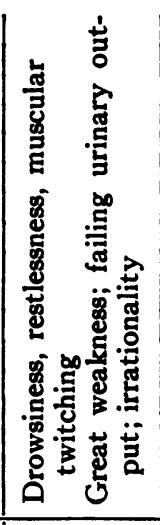 & 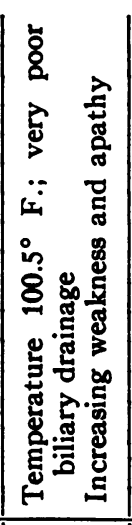 & 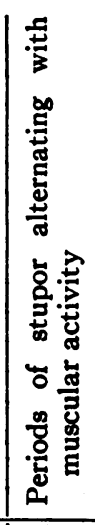 & 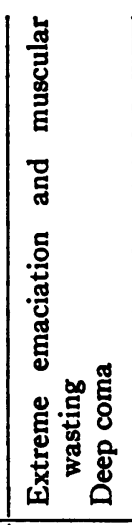 & 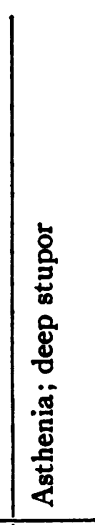 \\
\hline 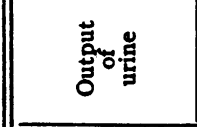 & $8:$ & 8 & 芯足 \& & $\begin{array}{ll}8 & 8 \\
9 & 8\end{array}$ & \begin{tabular}{ll}
8 & 8 \\
\hdashline & 8
\end{tabular} & \begin{tabular}{|l}
5 \\
$\frac{5}{5}$ \\
$\frac{5}{5}$ \\
5
\end{tabular} & $8 \%$ & 兽 \\
\hline 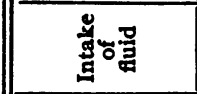 & s & 8 & 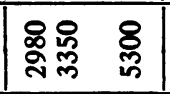 & 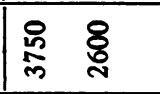 & $\begin{array}{|ll|}8 & 8 \\
0 & 8 \\
\end{array}$ & ${ }_{8}^{8}$ & $\begin{array}{ll}8 & 8 \\
9 & 8\end{array}$ & 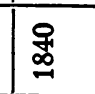 \\
\hline 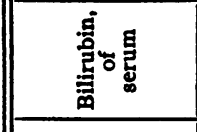 & 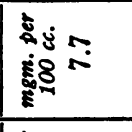 & 18 & 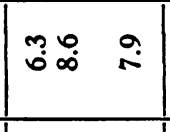 & fr & $\mid \begin{array}{ll}\hat{0} & 0 \\
0 & 0\end{array}$ & i & 象 & 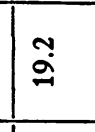 \\
\hline 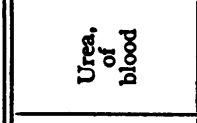 & 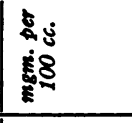 & I & $\Xi \Xi$ & $\approx$ & F & $\approx$ & 品品 & $\stackrel{\infty}{\infty}$ \\
\hline 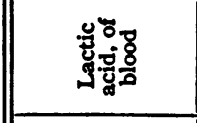 & 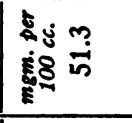 & 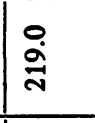 & 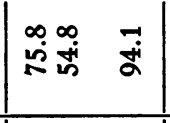 & 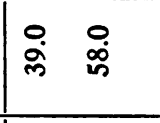 & 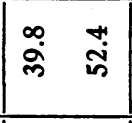 & 命 & 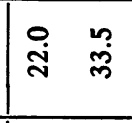 & 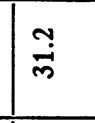 \\
\hline 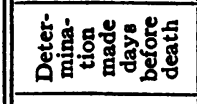 & in & $a$ & \begin{tabular}{ll|}
$-\infty$ & $N$
\end{tabular} & $m$ & \begin{tabular}{ll|}
0 & in
\end{tabular} & - & 90 & + \\
\hline 鄫 & 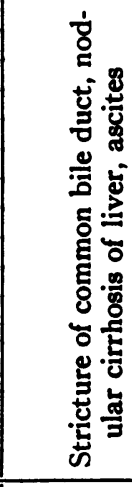 & 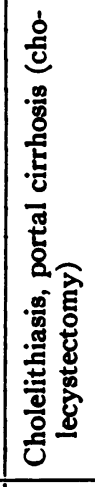 & 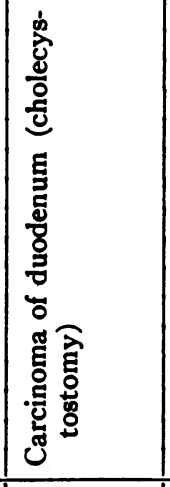 & 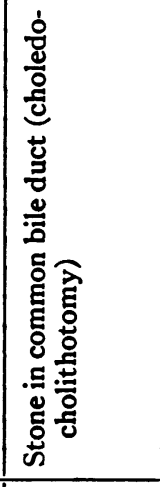 & 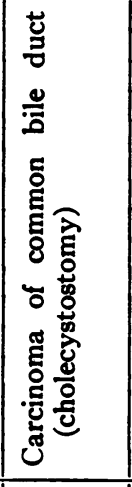 & 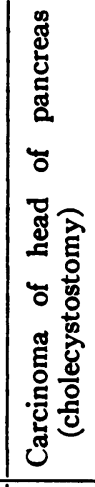 & 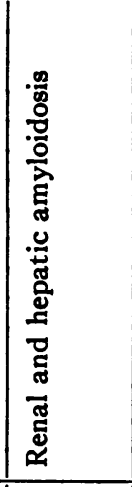 & 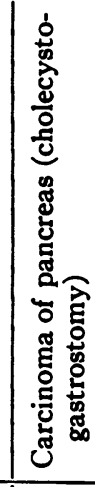 \\
\hline 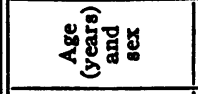 & 密 & 跑 & 点 & 衫 & 站 & 部 & 5 & $\sum$ \\
\hline है & - & | & m & $1+$ & in & 10 & 1- & $\mid \infty$ \\
\hline
\end{tabular}


blood were obtained in several of these cases. The same statement applies to patients not operated on, who displayed hepatic insufficiency as a terminal phenomenon. These accumulations of lactic acid in the blood are probably not to be ascribed to failure of hepatic function only, since they exceed considerably those which have been found in work with hepatectomized animals just before death. It is known that circulatory failure, anoxemia, and vomiting tend to increase the value for lactic acid in the blood, and these factors are all operative to a greater or lesser degree in clinical hepatic insufficiency. The presence of fever in these cases probably had a similar effect, although that produced by typhoid vaccine does not have a striking effect on patients who do not have hepatic disease. Some patients who have fever also present varying degrees of muscular rigidity, as well as periods of delirium associated with violent muscular activity, factors which also tend greatly to increase production of lactic acid. It is probable that the amounts of lactic acid formed in such cases can be eliminated only very slowly at best. All of these patients also presented moderate to marked renal insufficiency, with reduced output of urine and increased values for blood urea. Under these conditions, the renal threshold for lactic acid may be increased, thus introducing another factor which may elevate the value for lactic acid of the blood.

The total mass of actively functioning muscle tissue may also be a factor in these cases, as Schumacher has suggested. Lactic acid was most increased in the blood of the two most muscular and vigorous persons in the group.

In the last two cases presented in Table 2, the increase in blood lactic acid was slight. Both of the patients had been confined to bed for long periods, were emaciated, and had marked muscular wasting; both were in deep coma at the time the specimens of blood were taken. These factors no doubt explain the low values for lactic acid noted in these particular cases. In general, it may be said that the variations in metabolism of lactic acid noted in clinical states of hepatic insufficiency are probably due to factors other than hepatic failure only, and therefore are not particularly significant, so far as the liver is concerned.

The utilization of sodium lactate in hepatic disease. Solutions of racemic sodium lactate were administered intravenously to a group of eight patients with hepatic disease. The concentration used was that employed by Hartmann and Senn; the dosage was $4.5 \mathrm{cc}$. of molar solution of sodium lactate for each kilogram of body weight. Samples of blood were drawn at fifteen minutes, one hour, and two hours, following injection of this solution, and the content of lactic acid, sugar, and carbon dioxide was measured. No reactions following injection of this quantity of sodium lactate were seen among our patients, and they were in general unaffected by the procedure. The results of these tolerance tests are 


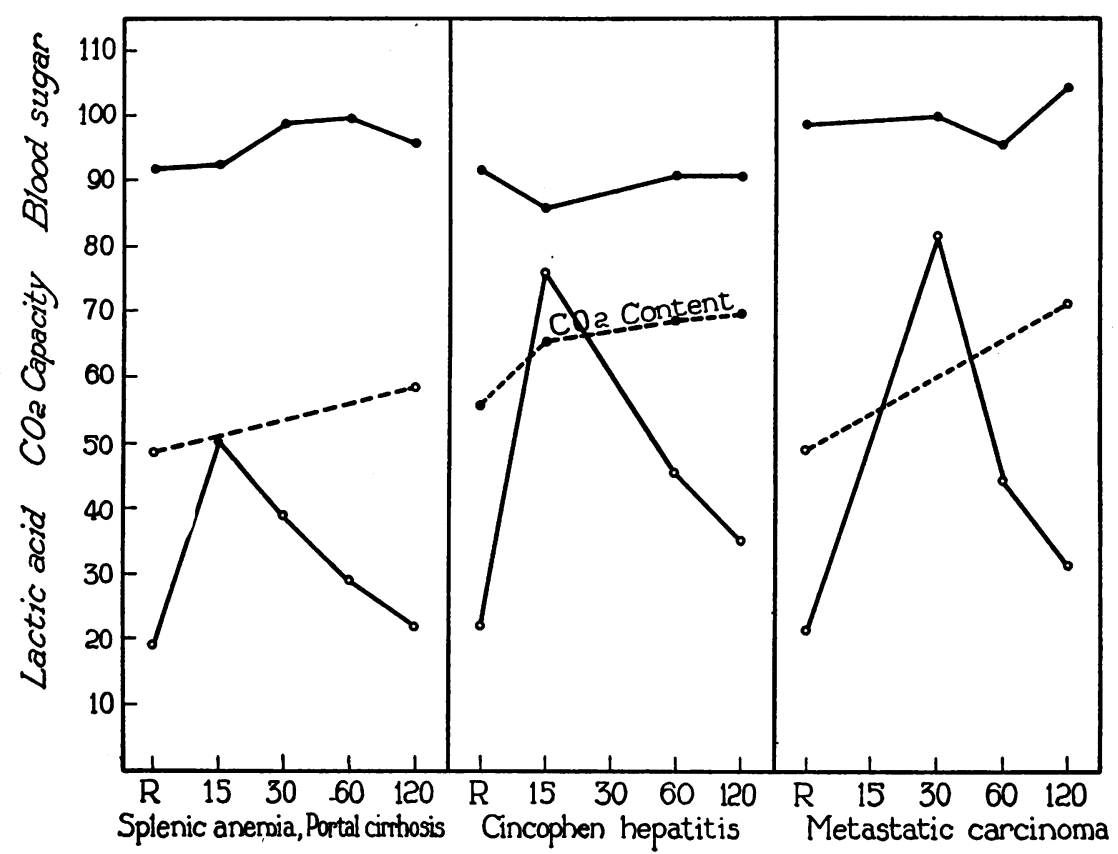

Fig. 4. The Utilization of Sodium r-Lactate in Various Types of Hepatic Disease

presented graphically in Figures 4 and 5. The value for lactic acid of the blood of one patient, who had almost completely recovered from jaundice caused by arsphenamine promptly declined following administration of sodium lactate, and in general gave a normal result. There was definite delay when compared with the normal figures given by Hartmann and Senn in disappearance of lactic acid from the blood following the injection, of one patient with metastatic carcinoma of the liver and one with splenic anemia and portal cirrhosis. Neither of these patients was jaundiced, but retention of bromsulphalein was graded 2 and 3, respectively. A third patient who was recovering from the effects of toxic hepatitis due to cinchophen, also retained injected sodium lactate to some degree. The degree of retention of lactic acid in each case corresponded closely with the clinical conception of the degree of hepatic injury present in the case, and in some instances also corresponded with the results either of the galactose or bromsulphalein tests for hepatic function (Table 3). Judging from the value for blood sugar in these cases, it is apparent that the lactic acid injected was either stored as glycogen in the liver or was utilized in some other fashion. As has previously been stated, similar disappearance of injected sodium lactate has been noted in work with hepatectomized animals. 


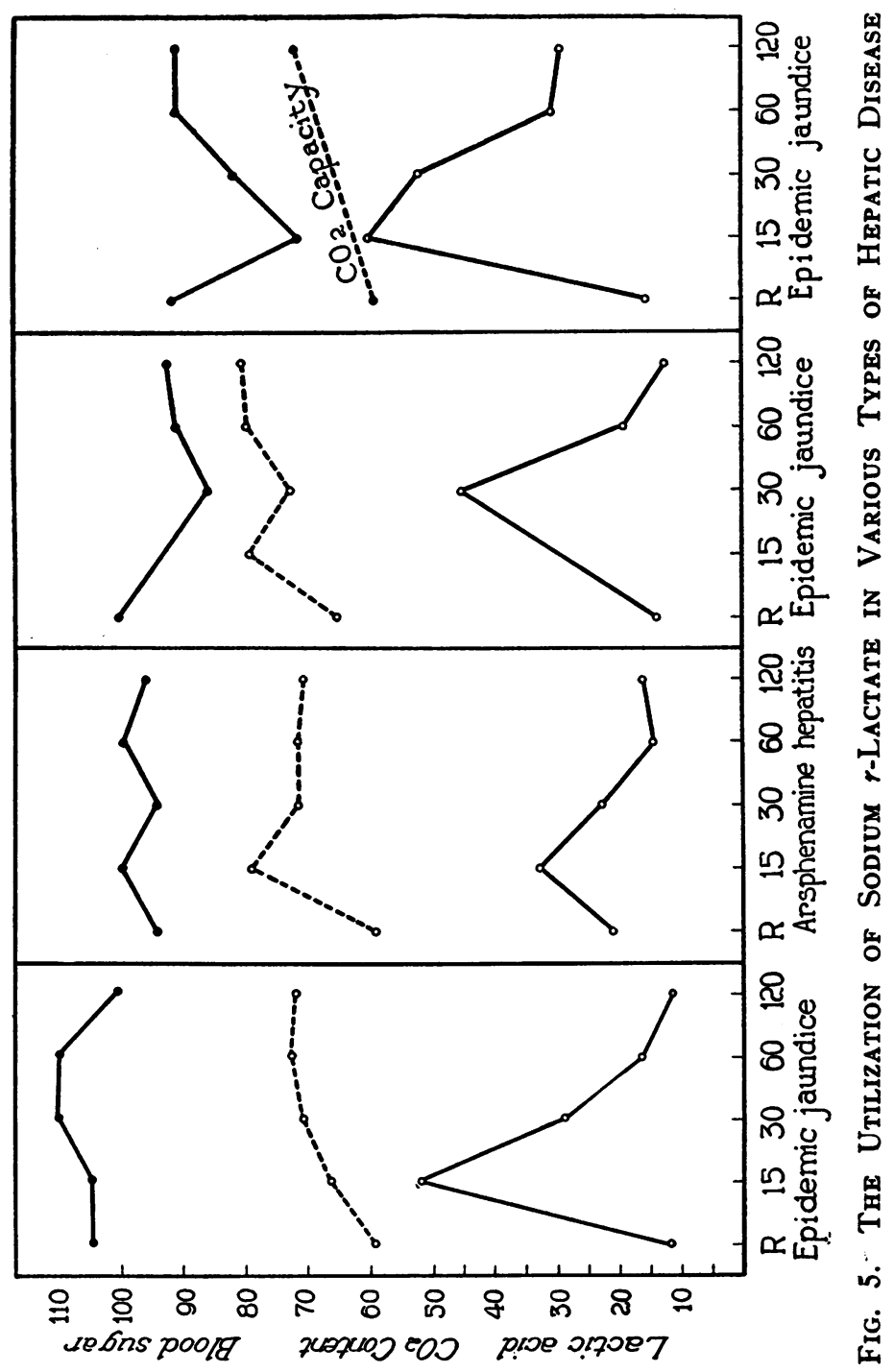


TABLE 3

Comparison of utilization of sodium lactate with results of bromsulphalein and galactose tests of hepatic function

\begin{tabular}{|c|c|c|c|c|c|c|}
\hline \multirow{2}{*}{ Diagnosis } & \multicolumn{3}{|c|}{$\begin{array}{l}\text { Sodium } r \text {-lactate metabolism } \\
\text { test, } 4.5 \text { oc. of molar solution } \\
\text { given intravenously for } \\
\text { each kgm. of body weight }\end{array}$} & \multirow{2}{*}{$\begin{array}{l}\text { Bilirubin, } \\
\text { of serum }\end{array}$} & \multirow{2}{*}{$\begin{array}{c}\text { Reten- } \\
\text { tion of } \\
\text { bromsul- } \\
\text { phalein, } \\
\text { grade }\end{array}$} & \multirow{2}{*}{$\begin{array}{l}\text { Excre- } \\
\text { tion of } \\
\text { galac- } \\
\text { tose }\end{array}$} \\
\hline & $\begin{array}{c}\text { Resting } \\
\text { value }\end{array}$ & $\underset{\text { rise }}{\text { Maximal }}$ & $\begin{array}{l}\text { Value } \\
\text { at end } \\
\text { of two } \\
\text { hours }\end{array}$ & & & \\
\hline & mgm. & mgm. & $m g m$. & $\begin{array}{l}\text { mgm. per } \\
100 \text { cc. }\end{array}$ & & grams \\
\hline 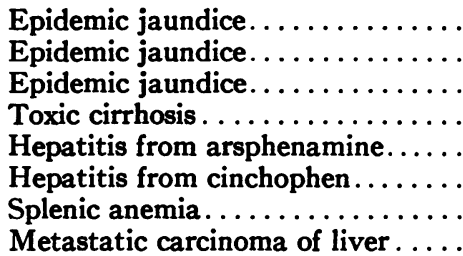 & $\begin{array}{l}15.3 \\
14.4 \\
12.2 \\
13.8^{*} \\
21.6 \\
22.5 \\
18.9 \dagger \\
22.1\end{array}$ & $\begin{array}{l}60.9 \\
45.5 \\
53.0 \\
26.3 \\
32.9 \\
76.2 \\
50.0 \\
83.4\end{array}$ & $\begin{array}{l}28.9 \\
13.1 \\
12.2 \\
12.5 \\
15.7 \\
35.6 \\
23.0 \\
32.5\end{array}$ & $\begin{array}{c}4.3 \\
5.2 \\
25.0 \\
13.6 \\
3.1 \\
5.4 \\
2.0 \ddagger \\
8\end{array}$ & $\begin{array}{l}3 \\
2\end{array}$ & $\begin{array}{l}4.5 \\
3.4 \\
3.7 \\
5.0 \\
1.3 \\
3.0\end{array}$ \\
\hline
\end{tabular}

* 10 grams of sodium $r$-lactate

$\dagger 2.25$ cc. of molar sodium $r$-lactate for each $\mathrm{kgm}$. body weight

$\ddagger$ Indirect

Indirect, less than 1.0

\section{COMMENT}

The increased values for lactic acid of the blood which we have obtained among patients with various types of hepatic disease are in general corroborative of those given by previous investigators of the subject. The average increases noted were somewhat greater than those previously reported, a fact which may be explained on the basis of differences in available clinical material and in the methods used to determine lactic acid. In general, our figures agree closely with those recently reported by Diaz and Cuenca, and by Massobrio and Michailoff.

We were able satisfactorily to exclude the effects of exercise, venous stasis, circulatory or respiratory disorders, and anemia in the cases under consideration. The most significant increases were found among patients with intrahepatic jaundice, and among those who had had biliary obstruction prolonged sufficiently so that the hepatic parenchyma had been greatly injured. In carcinomatous biliary obstruction, the high levels observed may be partially due to the presence of neoplastic tissue. In no instance, however, did the value for lactic acid of the blood materially exceed the renal threshold of 30 to $40 \mathrm{mgm}$. The maximal increases noted approximated those seen in studies of the experimental animal after hepatectomy, although the patients in question doubtless had an ample reserve of functioning hepatic tissue. In other cases, severe hepatic injury has been found to be associated with normal values for lactic acid. 
This seeming inconsistency is also noted in work with the hepatectomized animal. Liverless animals are capable of maintaining a fairly normal value for lactic acid for brief periods under resting conditions, but trivial degrees of muscular activity and various extraneous factors which would not affect a normal animal may cause an increase. In other words, the metabolism of lactic acid, although not entirely disrupted, is rendered considerably less stable after removal of the liver. The same is probably true in the more severe degrees of injury to the hepatic cell; under ideal conditions the normal value for lactic acid of the blood is maintained, but it is easily disturbed by any of the large number of factors known to affect it.

The truth of this statement is apparent when one considers the variable findings in clinical cases of hepatic insufficiency. Data concerning the blood lactic acid in such cases, which have been considered in a previous paragraph illustrate how a mechanism rendered unstable by hepatic injury can be affected by extraneous factors which may or may not have to do with hepatic function.

The variations in lactic acid of the blood which follow injection of racemic sodium lactate or lactic acid are worthy of brief mention. In hepatic disease, as in the hepatectomized animal, administration of lactic acid, or of lactate solutions, is apparently followed by utilization of a considerable amount of the injected material. The prompt disappearance of the excess of lactic acid from the blood under these conditions is of interest in view of the suggestion that lactic acid and lactates may be of therapeutic value in some types of hepatic disease. Morawitz has given lactic acid in doses of 10 grams, in cases of hepatic coma due to portal cirrhosis, and on at least one occasion the patient made a rather remarkable temporary recovery. We have had a similar experience with one patient who lapsed into hepatic coma following splenectomy for splenic anemia. Efforts to revive this patient by intravenous injections of solutions of glucose were unavailing. Lactic acid, 10 grams, in 2 per cent solution, was thereupon given daily for three days. The patient promptly recovered consciousness and remained in good condition for a few days, until death occurred as a result of hemorrhage from esophageal varices. In three other cases of marked hepatitis and jaundice, rapid improvement followed daily intravenous administration of this dose of lactic acid or of sodium lactate. All of these patients had been jaundiced for a considerable period of time, and appeared to be losing ground at the time the use of lactic acid was begun. The treatment, of course, is based on purely empirical grounds, but it seems worthy of further study in cases of this type.

SUMMARY

Slight to moderate increases in lactic acid of the blood are noted in hepatic disease; particularly significant changes are noted in the more 
severe grades of intrahepatic jaundice and in carcinomatous obstruction to the biliary passages. These increases are comparable to those observed after experimental hepatectomy, but in general they do not exceed the renal threshold for lactic acid of 30 to $40 \mathrm{mgm}$. for each $100 \mathrm{cc}$. of blood.

Much greater elevations of values for lactic acid of the blood are found in some cases of clinical hepatic insufficiency, but in these cases factors other than the functional capacity of the liver are responsible for the increases noted. Disappearance of injected sodium lactate from the blood of patients with hepatic disease is delayed in comparison to the rate of disappearance seen in work with normal persons. The results may be correlated roughly with those of bromsulphalein or galactose tests of hepatic function. As compared with the findings in studies upon normal persons, the regulation of blood lactic acid of hepatectomized animals, and of patients with disease of the liver, is considerably less stable, but is not completely disorganized.

\section{BIBLIOGRAPHY}

1. Adler, A., and Lange, H., Deutsches Arch. f. klin. Med., 1927, clvii, 129. Der Milchsaüregehalt des Blutes bei Leberkrankheiten.

2. Beckmann, Kurt, Klin. Wchnschr., 1927, vi, 2229. Resynthese der Milchsaüre bei Störungen der Leberfunktion.

3. Beckmann, Kurt, Ztschr. f. klin. Med., 1929, cx, 163. Klinische Erfahrungen mit der Leberfunktionsprüfung durch Milchsaürebelastung.

4. Beckmann, K., and Mirsalis, T., Deutsches Arch. f. klin. Med., 1928, clix, 129. Der Milschaüregehalt des Blutes nach Milchsaüreinjektion bei experimentellen Leberschädigungen.

5. Bollman, J. L., and Mann, F. C., Proc. Staff Meetings of Mayo Clinic, 1931, vi, 537. The Relation of the Liver to Metabolism of Lactates.

6. Büttner, H. E., Klin. Wchnschr., 1926, v, 1507. Blutmilchsaüre und Carcinom.

7. Campbell, W. R., and Maltby, E. J., J. Clin. Invest., 1928, vi, 303. On . the Significance of Respiratory Quotients after Administration of Certain Carbohydrates.

8. Cori, C. F., Physiol. Rev., 1931, xi, 143. Mammalian Carbohydrate Metabolism.

9. Cori, C. F., and Cori, G. T., J. Biol. Chem., 1929, lxxxi, 389. Glycogen Formation in the Liver from $d$ - and $l$-Lactic Acid.

10. Diaz, C. J., and Cuenca, B. S., Ann. de méd., 1930, xxviii, 501. Études cliniques sur l'utilisation de l'acide lactique.

11. Drury, D. R., and McMaster, P. D., Proc. Soc. Exp. Biol. and Med., 1929, xxvii, 48. Glucose Requirement of Hepatectomized Rabbits and Its Relation to Lactic Acid Production.

12. Eggleton, M. Grace, and Evans, C. L., J. Physiol., 1930, 1xx, 269. The Lactic Acid Content of the Blood after Muscular Contraction under Experimental Conditions.

13. Friedemann, T. E., and Kendall, A. I., J. Biol. Chem., 1929, lxxxii, 23. The Determination of Lactic Acid.

14. Gelstein, E. M., and Frankstein, M. I., Ztschr. f. klin. Med., 1929, cxi, 
563. Über Milchsaüregehalt im Blute bei einigen Erkrankungen und besonders bei Kranken mit malignen Neubildungen.

15. Hartmann, A. F., and Senn, M. J. E., J. Clin. Invest., 1932, xi, 345. Studies in the Metabolism of Sodium $r$-Lactate. III. Response of Human Subjects with Liver Damage, Disturbed Water and Mineral Balance, and Renal Insufficiency to the Intravenous Injection of Sodium $r$-Lactate.

16. Hewlett, A. W., Barnett, G. D., and Lewis, J. K., J. Clin. Invest., 1926, iii, 317. The Effect of Breathing Oxygen-Enriched Air During Exercise Upon Pulmonary Ventilation and Upon the Lactic Acid Content of Blood and Urine.

17. Himwich, H. E., Yale J. Biol. and Med., 1932, iv, 259. The Rôle of Lactic Acid in the Living Organism.

18. Himwich, H. E., Koskoff, Y. D., and Nahum, L. H., J. Biol. Chem., 1930, lxxxv, 571. Studies in Carbohydrate Metabolism. I. A GlucoseLactic Acid Cycle Involving Muscle and Liver.

19. Jervell, Otto, Acta med. Scandin., 1928, supp. 24, 1. Investigation of the Concentration of Lactic Acid in Blood and Urine under Physiologic and Pathologic Conditions.

20. Jervell, Otto, Norsk. mag. f. Laegevidensk., 1930, xci, 528. Melkesyrebestemmelse i blod ved kreft og leversykdommer.

21. Loeb, R. E., Reeves, Esther B., and Glasier, H. P., J. Clin. Invest., 1931, $x, 19$. Responses to the Injection of Epinephrine in Hepatic Disease.

22. Mann, F. C., and Magath, T. B., Arch. Int. Med., 1922, xxx, 73. Studies on the Physiology of the Liver. II. The Effect of the Removal of the Liver on the Blood Sugar Level.

23. Massobrio, E., and Michailoff, M., Minerva med., 1930, xxi, i, 650. Sul comportamento dell'acido lattico del sangue nelle epatopatie.

24. Meakins, Jonathan, and Long, C. N. H., J. Clin. Invest., 1927, iv, 273. Oxygen Consumption, Oxygen Debt, and Lactic Acid in Circulatory Failure.

25. Mendel, Bruno, Engel, Werner, and Goldscheider, Ingelborg, Klin. Wchnschr., 1925, iv, 262. Über den Milchsaüregehalt des Blutes unter physiologischen und pathologischen Bedingungen.

- 26. Minkowski, O., Arch. f. exper. Path. u. Pharmakol., 1886, xxi, 41. Ueber den Einfluss der Leberexstirpation auf den Stoff wechsel.

27. Morawitz, Paul. Personal communication to the authors.

28. Noah, G., Klin. Wchnschr., 1927, vi, 1465. Milchsaüreuntersuchungen im Blut, insbesondere bei Leberkrankungen.

29. Noah, G., Ztschr. f. d. ges. exp. Med., 1928, lxi, 59. Über des Verhalten des Blutmilchsaürespiegels bei normalen und leberkranken Kaninchen.

30. von Noorden, C., and Embden, G., Zentralbl. f. d. ges. Physiol. u. Path. d. Stoffwechs., 1906, 1, 2. Einige Probleme des intermediären Kohlenhydratstoff wechsels.

31. Ronzoni, Ethel, Koechig, Irene, and Eaton, Emily P., J. Biol. Chem., 1924, lxi, 465. Ether Anesthesia. III. Rôle of Lactic Acid in the Acidosis of Ether Anesthesia.

32. Schneider, Erich, and Widmann, Ernst, Klin. Wchnschr., 1930, ix, 761. Das Verhalten der Leber bei Milchsaürezufuhr von der Vena portae aus.

33. Schumacher, Hertha, Klin. Wchnschr., 1926, v, 497. Untersuchungen über den Milchsäuregehalt des Blutes bei Karzinomkranken.

34. Schumacher, Hertha, Klin. Wchnschr., 1928, vii, 1733. Das Verhalten der Blutmilchsaüre bei Leberkranken. 
35. Valentin, F., München. med. Wchnschr., 1925, lxxii, 86. Ueber den Milchsaüregehalt des Blutes.

36. Wakefield, E. G., and Greene, C. H., Ann. Int. Med., 1930, iii, 793. The Lactic Acid Content of the Blood and the Partition of Inorganic Sulphate in the Serum of Patients with Hepatic Disease.

37. Wierzuchowski, M., and Laniewski, M., Biochem. Ztschr., 1931, ccxxx, 173. Intermediärer Kohlenhydratstoff wechsel. VII. Milchsaüreproduktion bei intravenöser Dauerinjektion der Glykose, Fruktose, und Galaktose. 